The Department of Terrestrial Magnetism continued its laboratory synthesis of minerals to obtain further understanding of the composition and structure of the Earth. Measurements, in collaboration with the University of Wisconsin, on the North Carolina oceanic shelf, of the arrival velocities of Earth waves produced by specially set explosions, using new recording-array procedures, indicated that in that area the Earth's crust is at a depth of about 22 miles. The investigations also point to the probability that the rocks in the lower part of the Earth's crust are a continuously changing mixture in which the importance of the iron-magnesium minerals in chemical composition increases with depth. In the same Department the Biophysics Group developed the use of singlestranded deoxyribonucleic acid as an adsorption column to select closely related genetic units from another organism on complementary ribonucleic acid or deoxyribonucleic acid. Through this deoxyribonucleic acid-agar technique, significant interrelations have been traced among severa varieties of bacteria and also between bacteria and associated viruses (bacteriophages). Preliminary experiments have also shown significant homology, or relation, between deoxyribonucleic acid from human tissues and from the tissues of animals, and the Group believes that these results imply the existence of some common genetic material that has been conserved during the course of vertebrate evolution, including some genetic homology extending from man to fishes. It is believed that the sensitivity of the method can be increased sufficiently to provide new evidence on the most probable line of evolution of the vertebrates from the invertebrates. The Department also supports the work of the Carnegie Committee on Image Tubes for Telescopes, which this year has surmounted previous difficulties with resolving power and uniformity of phosphor screens. The Committee is able to recommend the purchase of 30-80 image tubes of two or three types which will give an advantage of a factor of 10 or more over the direct use of photographic emulsions.

The Department of Plant Biology continued to be concerned mainly with the functional relations and the chemical nature of the various plant pigments that absorb light to supply energy for the various reactions. Measurements of the rate of photosynthesis were made with short light flashes of colours chosen to activate specific pigment systems of algae and a clear separation of the functions of several forms of chlorophyll $a$ was alse achieved. Analysis of accumulated data from long-term genetic and transplant experiments on Achilla and Mimulus with the help of an electronic computer indicated that the principle of genetic coherence which emerged from earlior work on Potentilla is a general one. Biochemical investigations have been started on the key clones of Mimulus cardinalis. An experimental instrument was constructed using an optical range-finder for plane-table mapping in such a way that a point observed through the range-finder telescope is automatically located on the map by an index marker, while the elevation of this point simultaneously appears on a dial and the instrument does all the calculating and plotting.

The Departmont of Embryology reports substantial progress in a large-scale investigation of the metabolism of the early chick embryo. A substantial part was completed of a comprehensive investigation of the normal and abnormal development of the human heart in relation to corrected transpiration of the great vessels. In developmental biology the report records observations on Drosophila, the embryos of the frog, monkey and man, on tumour viruses and interferon, and on rabbits and thalidomide, using techniques of enzymology, immunology and X-ray cinematography. The Genetics Research Unit reports on the work on some idiosyncrasies of phage deoxyribonucleic acid structures, on some further investigations of gene-control systems in maize, and on the preparation of $Z$ protein from ribonuclease and the properties of $Z$ protein. A report from the Cytogenetics Laboratory reviews work on chromosome structure and function, including the progress of spermatogenesis in Drosophila, the histone transition during Drosophila spermiogenesis, and investigations of the xnicrosporogenesis in Tradescantia paludosa, as well as on the incorporation of ${ }^{3} \mathrm{H}$-thymidine in bonds of the great chromosomes of the Drosophila salivary glands.

\title{
INTERNATIONAL INDIAN OCEAN EXPEDITION
}

T HE Royal Society has issued a preliminary cruise report on the first part of the contribution made by the new R.R.S. Discovery to the International Indian Ocean Expedition*, in which the ships of many nations are making systematic investigations of special problems and areas as well as general surveys. The Discovery's first task was to delimit the area of upwelling off the South Arabian coast during the period of the south-westerly monsoon, and to investigate its mechanism, and the ensuing cycle of chemical and biological changes. The current measurements showed that the predominantly offshore movement at the surface and inshore movement at depths of 100-200 $\mathrm{m}$ could be balanced by a vertical movement of about $4 \mathrm{~m}$ a day near the coast, and this agreed fairly well with the measurements of radiation falling on the surface and of the rise in temperature away from the coast. When the density and pressure distributions are calculated from the hydrographic observations a more complete picture will be obtained. The closely spaced observations show great complexity in detail. Antarctic intermediate water was traced into the Gulf of Aden, where there is a 'reference station' at which all ships will try to make observations. Deep water from the Persian Gulf was detected all along the continental slope

* International Indian Ocean Expedition R.R.S. Discovery. Cruise 1: South-east Arabian Umwelling Region. Pp. 24+15 Figs. (I.ondon: The Royal Society, 1963.) of Arabia, and current measurements in it, at $200 \mathrm{~m}$ and below, showed a predominantly south-westerly movement contrary to the prevailing trend of the surface flow along the coast. Deep water from the Red Sea was very obvious in the Gulf of Aden, but not near the Arabian coast. It appears to take a more southerly direction as will, no doubt, be shown by the observations of other ships.

The richest phytoplankton was found near the coast. particularly between the surface and $20 \mathrm{~m}$. Beyond about 20-30 miles from the coast it was somewhat less and the level of maximum abundance was deeper. The greatest concentration, $64 \times 10^{3}$ cells/l., occurred near the coast at Ras Fartak, and 200 miles offshore surface concentrations were about $3.5 \times 10^{3}$ cells/1. Rates of growth and photosynthesis were measured. The highest concentrations of zooplankton occurred at stations on the continental shelf, but the total amount in the $0-100-\mathrm{m}$ water column was greatest in deep water just off the edge of the sholf. 15-min hauls with a net made to skim the surface and sample the upper $10 \mathrm{~cm}$ of water abeam of the ship took substantial numbers of larvæ similar to the published descriptions of tuna larvæ, many post-larval Carangiid fish, and flying fish. (In the Mediterranean Sea the catches were spoilt by floating oil.) Benthic sampling, done with a grab, was designed specially to investigate the ecology of the very small forms, but the samples also give evidence of fairly rich popula- 
tions of Crustaceans and Polychaetes at depths of $600-$ $1,000 \mathrm{~m}$.

The period of investigation was at the height of the south-westerly monsoon, too early to investigate the after-effects of the very high productivity. There was no hydrogen sulphide in the oxygen-minimum layor, and anaerobic bacteria were present at one inshore station only and not obviously related to the oxygen-minimum layer. The aerobio heterotrophic bacteria were reasonably well correlated with the abundance of zooplankton. A definite diminution in bacterial numbers was observed with increasing depth at all stations off the continental shelf, but not in inshore waters.

Routine analyses were made for the principal nutrients and special analyses were made for ammonium and albuminoid nitrogen, trace metals, dissolved organic substances and particulate nitrogen, phosphorus and carbon. There was a remarkably constant phosphorusnitrogen ratio in the deep layers.

The ship carried special echo-sounding and ranging equipment with frequencies of 10,36 and $54 \mathrm{kc} / \mathrm{s}$, and different pulse-lengths and beam angles, to experiment with acoustic methods of investigating the distribution of plankton and fish. Almost continuous records have been obtained but not yet examined. They include evidence of large fish shoals.
A comprehensive ornithological programme was carried out, and when the observations are brought together with the other biological data they are likely to tell us much about the ecological factors which affect the distribution of the sea-birds in this area.

Four Royal Society John Murray students were carried in the ship and altogether representatives of nine laboratories as well as of the Hydrographic Department, Admiralty. When the ship returned to Aden on August 20 , most of the scientific staff changed over, ten scientists from the Department of Geodesy and Geophysics, Cambridge, and three from the National Institute of Oceanography replacing those who left. Two of the biologists went to Zanzibar and one to Cochin, and two chemists and the ornithologist remained on board the ship. The next part of the work, a detailed topographical, geological, seismic and magnetic investigation of the Carlsberg Ridge and the western basin between the African coast and the Seychelles Bank, will be the subject of a second eruise report. By the time the Discovery returned to Plymouth on December 4 she had spent 163 days at sea with only 24 in port, a great deal of the work had been done and she had steamed 28,000 miles. The fact that this was possible is due particularly to Captain C. Alexander and the chief engineer, Mr. T. Humphrey.

G. E. R. DEACON

\section{THE BRITISH COUNCIL}

$\mathrm{B}$ ESIDES the customary review of the year, the annual report of the British Council for 1962-63* includes an article by John Press on "Patterns of Interchange", which explains just how the British Council functions in this field both in organizing the outward flow, assisting visitors to Britain, including overseas students, and finally, the way in which English serves as the medium of exchange. Although less than 500 persons are involved in the Council's work in supplying experts on overseas visits as advisers and lecturers, their importance in the pattern of interchange is disproportionate to their numbers. In science and technology the total has grown from 17 in $1952-53$ to 99 in $1962-63$; in medicine from 14 to 95 ; in education from 8 to 106 ; in social science from 4 to 32 ; and in arts and humanities from 27 to 102 . In the same period the number of visitors to Britain assisted by the Council has grown from 3,703 to 8,315 , and the proportion financed by the Council from 17 per cent to 29 per cent. Nearly 1,400 of the $1962-63$ total were professional men and women who came to Britain on the recommendation of the Council's representatives abroad, and 400 of them came to investigate some aspect of British education, the interests of the remainder being divided among science, technology, social science, medicine, the arts and humanities.

Mr. Press describes clearly just how the Council's effort is organized and spread out over Britain. At the same time, the number of Fellows, scholars, trainees, etc., financed under technical assistance and other schemes which the Council helps to administer in Britain has grown from 662 in $1952-53$ to 3,120 in 1962-63; the great bulk of these are now Commonwealth Fellows, scholars and bursars, United Nations Fellows, trainees, etc., or Colombo Plan trainees. Overseas students in Britain have increased from 14,977 in $1952-53$ to 64,319 in 1962-63, of whom 13,919 are university students; 9,576 were met and given arrival services by the Council $(3,759$ in 1952), while 9,618 were assisted to find permanent accommodation (352 in Council residences, 1,217 in other residences, and 8,049 in lodgings). Most of the $£ 3$ million administered for the Government by the Council on welfare

* The British Council. Annual Report 1962-1963. Pp. vii $+118+12$ plates. (London: H.M.S.O., 1963.) 2s. 6d. net. services for overseas students is being spent on providing 5,000 new places in hostels run by voluntary bodies, but some is spent in improving amenities at the Council's own centres in London.

Receipts from earnings and donations brought the Council's income for the year to $£ 8,039,000$, of which Government grants amounted to $£ 7,466,000$, and the gross budget for $1963-64$ is $£ 9.26$ million. A start was made with the Aid to Commonwealth English Scheme, under which 30 additional British experts are being recruited to the Council's permanent staff over the years 1962-64; after training, they will become trainers of local teachers of English overseas and advisers to Commonwealth Governments on English teaching methods. The Council's English teaching work in Africa has also been greatly strengthened and its English-Teaching Information Centre in State House, London, W.C.1, is now well established. Under the pilot scheme run by Voluntary Service Overseas in 1962, the Council helped 36 graduates to teach in schools and universities in Africa and the number for 1963-64 is being increased to 250 .

Under the Council's Scholarship Scheme, since 1937, more than 5,000 people, mostly postgraduates, have held scholarships, and in the past ten years 29 have become university professors. The Bridges Committee on Training in Public Administration for Overseas Countries recommended that the Council and the Department of Technical Co-operation should jointly provide staff for a unit to co-ordinate training arrangements in this field; this unit has already begun work. Three years of steady development in the flow of British books and periodicals overseas were followed by a temporary check in 1962-63 through the Government's decision to reduce overseas expenditure, and some proposals for developing public library systems in developing Commonwealth countries had to be postponed, but since 1958-59 the number of Council libraries has increased from 99 to 139 and annual issues from them have doubled to 3.5 million. Nearly 100,000 volumes were presented to schools and universities and similar institutions in 1962-63 (18,000 in 1958-59).

While hitherto most of the Council's scientific work has been directed at the graduate or senior postgraduate, more assistance is now being given to scientific education 